\title{
IDENTIFIKASI BAKTERI DAN RESISTENSINYA TERHADAP ANTIBIOTIK DI POLI GIGI RSUD dr. DORIS SYLVANUS PALANGKA RAYA ${ }^{1}$ Susi Novaryatiin
}

\author{
${ }^{1}$ Dosen Pengajar Program Studi D-III Farmasi, Fakultas IImu Kesehatan, \\ Universitas Muhammadiyah Palangkaraya \\ e-mail : susi_novaryatiin@yahoo.com
}

\begin{abstract}
ABSTRAK
Rumah sakit selain merupakan tempat untuk mendapatkan kesembuhan, namun juga merupakan sumber dari berbagai macam penyakit, terutama penyakit yang disebabkan oleh bakteri. Bakteri dapat hidup dan berkembang di lingkungan rumah sakit, seperti air, udara, lantai, makanan, dan benda-benda peralatan medis maupun non medis. Beberapa penyakit yang dapat ditularkan di rumah sakitk hususnya dalam pelayanan kesehatan gigi antara lain herpes simpleks, tuberkulosis, hepatitis B, AIDS, sifilis, campak, dan infectious mononucleids.

Penemuan antibiotik membawa dampak besar pada pelayanan kesehatan dan penyembuhan infeksi bakteri. Akan tetapi, saat ini pola penggunaan beberapa antibiotic telah berlebihan dan tidak tepat. Hal ini dapat menyebabkan terjadinya resistensi bakteri terhadap antibiotik.

Penelitian ini bertujuan untuk mengetahui bakteri apa saja yang terdapat di Poli Gigi RSUD dr. Doris Sylvanus Palangka Raya dan untuk mengetahui resistensi bakteri yang ditemukan terhadap antibiotik yang digunakan di Poli Gigi RSUD dr. Doris Sylvanus Palangka Raya.

Penelitian ini dilakukan di Laboratorium Mikrobiologi Fakultas IImu Kesehatan Universitas Muhammadiyah Palangkaraya. Kegiatan penelitian yang dilakukan adalah pengambilan sampel, isolasi bakteri, identifikasi bakteri, dan uji resistensi antibiotik.

Pada penelitian ini telah berhasil diisolasi dan diidentifikasi bakteri Staphylococcus sp. dan E. coli dari Poli Gigi RSUD dr. Doris Sylvanus Palangka Raya. Baik Staphylococcus sp. maupun E. coli menunjukkan sensitivitas yang baik terhadap ketiga antibiotik yang sering digunakan di Poli Gigi RSUD dr. Doris Sylvanus Palangka Raya.Staphylococcus sp. menunjukkan sensitivitas yang tinggi terhadap cefadroxil, diikuti oleh clindamycin dan amoxicilin. SedangkanE. coli menunjukkan sensitivitas yang tinggi terhadap clindamycin, diikuti oleh amoxicilin dan cefadroxil.
\end{abstract}

Kata Kunci: identifikasi bakteri, resistensi antibiotik, Staphylococcus sp., E. coli, Poli Gigi RSUD dr. Doris SylvanusPalangka Raya.

\section{PENDAHULUAN}

Rumah sakit merupakan tempat dimana orang yang sakit dirawat untuk mendapatkan terapi dan perawatan agar dapat sembuh. Namun, disamping untuk mencari kesembuhan, rumah sakit juga merupakan sumber dari berbagai macam penyakit, terutama penyakit yang disebabkan oleh bakteri. Bakteri dapat hidup dan berkembang di lingkungan rumah sakit, seperti air, udara, lantai, makanan, dan benda-benda peralatan medis maupun non medis. Udara dari dalam ruangan dapat bertindak sebagai reservoir bakteri patogen 
yang ditularkan oleh pasien, sehingga dapat menyebabkan terjadinya infeksi (Noer, 2012).

Infeksi baru yang diperoleh dari rumah sakit dan sebelumnya tidak dalam masa inkubasi dari penyakit tersebut, inilahyang disebut dengan infeksi nosokomial (Kusmawan, 2008). Di negaranegara berkembang, kejadian infeksi nosokomial tinggi disebabkan karena kurangnya pengawasan, praktik pencegahan infeksi yang buruk, pemakaian sumber terbatas yang tidak tepat, dan rumah sakit yang penuh sesak (Irianto, 2013).

Tindakan perawatan di poli gigi yang beresiko terhadap penularan penyakit antara lain berupa tindakan pencabutan gigi, pembersihan karang gigi, pengasahan gigi terutama di daerah servikal (daerah yang berbatasan dengan gusi), insisi, serta tindakan lain yang dapat menimbulkan luka. Beberapa penyakit yang dapat ditularkan dalam pelayanan kesehatan gigi antara lain herpes simpleks, tuberkulosis, hepatitis $B$, AIDS, sifilis, campak, dan infectious mononucleids (Kusmawan, 2008).

Penemuan antibiotik membawa dampak besar pada pelayanan kesehatan dan penyembuhan infeksi bakteri. Menurut Waluyo (2008), secara klinis antibiotik yang baik mempunyai sifat membunuh bakteri yang bersifat patogen tanpa merusak inang, bakterioside, tidak menyebabkan resistensi bakteri, berspektrum luas, dan tidak alergenik dalam jangka waktu penggunaan yang lama.

Di Indonesia, antibiotik yang cukup dominan digunakan yaitu tetrasiklin, penisilin, kloramfenikol, eritromisin, dan streptomisin. Tidak berbeda dengan negara lain, pola penggunaan antibiotik tersebut telah berlebihan dan banyak diantaranya digunakan secara tidak tepat. Hal ini menyebabkan terjadinya resistensi bakteri terhadap antibiotik (Hadinegoro, 1999).

Berdasarkan latar belakang di atas, maka perlu dilakukan penelitian terhadap pola bakteri dan resistensinya terhadap antibiotik di Poli Gigi RSUD dr. Doris Sylvanus. Diharapkan hasil penelitian dapat dijadikan pertimbangan dalam pedoman pemberian antibiotik di rumah sakit, khususnya di poli gigi.

Penelitian ini bertujuan untuk mengetahui bakteri apa saja yang terdapat di Poli Gigi RSUD dr. Doris Sylvanus Palangka Raya dan untuk mengetahui resistensi bakteri yang ditemukan terhadap antibiotik yang digunakan di Poli Gigi RSUD dr. Doris Sylvanus Palangka Raya.

\section{METODE PENELITIAN}

Penelitian ini dilakukan di Laboratorium Mikrobiologi Fakultas IImu Kesehatan Universitas Muhammadiyah Palangkaraya. Penelitian dilaksanakan selama 4 (empat) bulan dimulai dari sejak 
penelitian ini disetujui oleh LP2M UM Palangkaraya. Kegiatan penelitian yang dilakukan adalah pengambilan sampel, isolasi bakteri, identifikasi bakteri, dan uji resistensi antibiotik.

\section{Sampel Penelitian}

Sampel penelitian adalah air dan udara ruang di Poli Gigi RSUD dr. Doris Sylvanus Palangka Raya. Sampel air diambil sebanyak $100 \mathrm{ml}$ dengan menggunakan botol sampel steril. Untuk pengambilan sampel bakteri udara ruang diambil pada 3 (tiga) tempat yang membentuk garis diagonal (pada saturuangan) yaitu 1 (satu) di sudut, 1 (satu) di tengah, dan 1 (satu) di sudut. diambil pada 3 (tiga) titik yaitu 2 (dua) titik pada sudut ruangan dan 1 (satu) titik pada tengah ruangan.

\section{Isolasi Bakteri}

Bakteri yang tumbuh pada media NA kemudian ditumbuhkan pada media $\mathrm{BHI}$, diinkubasi pada suhu $37{ }^{\circ} \mathrm{C}$ selama 24 jam pada inkubator. Lalu ditumbuhkan pada media diferensial antara lain media EMBA dan media Blood Agar.Penumbuhan bakteri dari media $\mathrm{BHI}$ ke media diferensial dapat dilakukan dengan cara goresan. Inkubasi dilakukan pada suhu $37{ }^{\circ} \mathrm{C}$ selama $18-24$ jam (Hadioetomo, 1993).

\section{Identifikasi Bakteri}

Isolat bakteri yang diperoleh lalu dikultur, kemudian diidentifikasi untuk menentukan pola bakteri. Identifikasi bakteri dilakukan berdasarkan sifat-sifat bakteri dengan menggunakan pewarnaan gram (Hadioetomo, 1993).Amati preparat di bawah mikroskop.

\section{Uji Resistensi Antibiotik}

Uji resistensi antibiotik dilakukan dengan metode Kirby Bauer (Koneman et.al.,1988), dengan menggunakan media MHA.Beberapa koloni bakteri yang sudah ditumbuhkan selama 24 jam diambil untuk disuspensikan ke dalam 0,5 $\mathrm{ml} \mathrm{BHI}$ cair, lalu diinkubasi pada suhu $37^{\circ} \mathrm{C}$ selama 5-8 jam. Suspensi di atas ditambah aquades steril hingga kekeruhan tertentu sesuai dengan standar Mac Farlan konsentrasi bakteri $10^{8}$ CFU per ml.

Kapas lidi steril dicelupkan ke dalam suspensi bakteri lalu ditekan-tekan pada dinding tabung hingga kapasnya tidak terlalu basah, kemudian dioleskan pada permukaan media agar hingga merata. Disk antibiotik diletakkan di atas media agar yang telah diolesi bakteri, kemudian diinkubasi pada suhu $37{ }^{\circ} \mathrm{C}$ selama $18-24$ jam. Daerah hambatan antibiotik terhadap pertumbuhan bakteri diukur menggunakan penggaris dengan satuan $\mathrm{mm}$.

\section{HASIL DAN PEMBAHASAN}

\section{Isolasi Bakteri}

Pengambilan sampel pada ruangan Poli Gigi BLU RSUD dr. Doris Sylvanus Palangka Raya menghasilkan sebanyak 4 sampel. Pengambilan sampel dapat diuraikan pada Tabel 1 berikut. 
Tabel 1. Hasil Pengambilan Sampel

\begin{tabular}{ccc}
\hline Sampel & Jumlah Sampel & Kode \\
\hline Udara & 3 & U1, U2, U3 \\
Air & 1 & A \\
\hline Total & 4 & \\
\hline
\end{tabular}

Dari keempat sampel yang diambil, Mikroba yang memfermentasi laktosa semuanya tumbuh pada media NA. menghasilkan koloni ungu gelap dengan Selanjutnya bakteri yang tumbuh tersebut kemilau hijau metalik, sedangkan mikroba lain ditumbuhkan pada media BHI, lalu yang dapat tumbuh koloninya tidak berwarna. ditumbuhkan pada media diferensial. Media Pada penelitian ini diamati adanya diferensial yang digunakan yaitu media EMBA pertumbuhan bakteri pada media EMBA, dan media Blood Agar.

Media EMBA merupakan media diferensial yang berasal dari sampel air. Koloni yang yang digunakan untuk deteksi dan isolasi tumbuh berwarna ungu gelap dengan kemilau hijau metalik yang tidak terlihat (Gambar 1 ). pathogen Gram negatif usus (fecal bacteria).

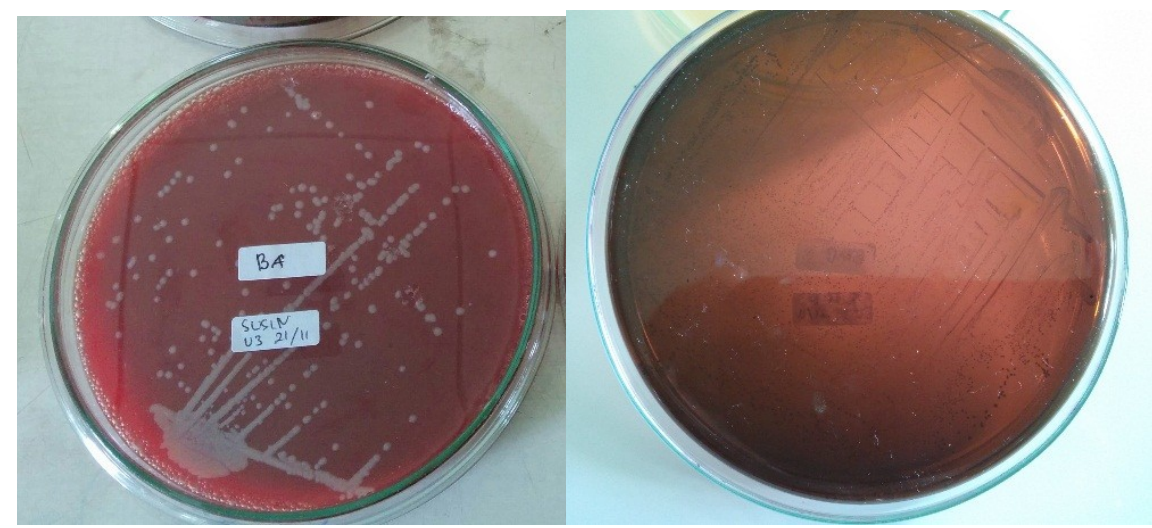

Gambar 1.Pertumbuhan bakteri pada media EMBA (kanan) dan media Blood Agar (kiri).

$\begin{array}{lrl}\text { Media Blood Agar digunakan untuk } & \text { bukan merupakan } & \text { Streptococcus sp. } \\ \text { deteksi dan isolasi bakteri berdasarkan } & \text { (Gambar 1). } \\ \text { kemampuannya untuk melisiskan sel-sel } & \text { Identifikasi Bakteri } \\ \text { darah merah. Ketiga sampel udara pada } & \text { Hasil pengamatan pewarnaan Gram di } \\ \text { penelitian ini menunjukkan adanya } & \text { bawah mikroskop diperoleh } 1 \text { bakteri Gram } \\ \text { pertumbuhan bakteri pada media Blood Agar. } & \text { positif dan } 1 \text { bakteri Gram negatif. Bakteri } \\ \text { Tidak adanya zona hemolisis yang terbentuk } & \text { Gram positif tampak berwarna ungu tua dan } \\ \text { menunjukkan bahwa bakteri yang tumbuh } & \text { berbentuk bulat bergerombol. Warna ungu }\end{array}$


dihasilkan akibat mempertahankan zat pewarna kristal violet. Sedangkan bakteri Gram negatif tampak berbentuk batang dan berwarna merah akibat kehilangan 2007). zatpewarna kristal violet. Perbedaan warna ini disebabkan oleh perbedaan dalam struktur kimiawi dinding sel bakteri (Pelczar dan Chan,

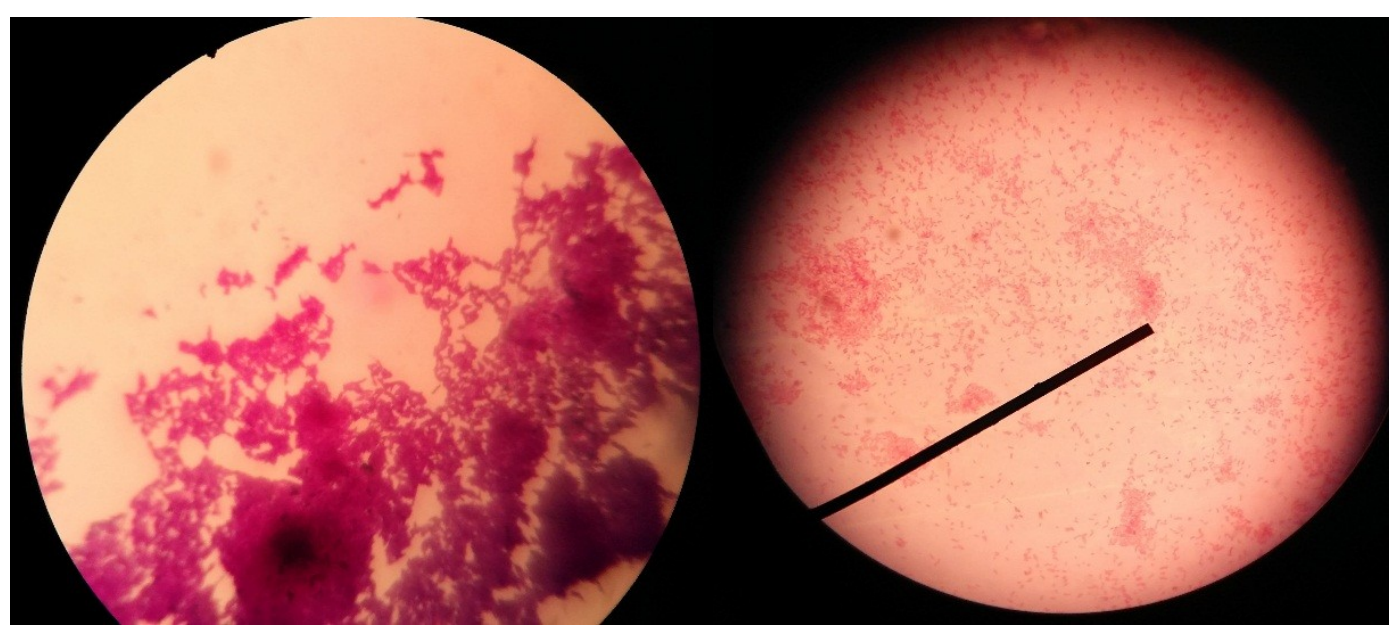

Gambar 2. Pewarnaan Gram Staphylococcus sp. (kiri) danE. coli (kanan)

Berdasarkan pertumbuhan bakteri Enterobacteraceae, bersifat anaerob pada media diferensial dan pengamatan morfologi dengan pewarnaan Gram, maka bakteri Gram positif diidentifikasi sebagai Staphylococcus sp. (Gambar 2). Staphylococcus adalah bakteri Gram positif yang menghasilkan pigmen emas dan putih, bersifat aerob fakultatif, tidak menghasilkan spora dan tidak motil, umumnya tumbuh berpasangan maupun berkelompok, berbentuk bulat dengan diameter sekitar 0,81,0 $\mu \mathrm{m}$ (Adam, 1992 dan Brooks, 2007).

Sedangkan bakteri Gram negatif yang berhasil diisolasi pada penelitian inidiidentifikasi sebagai Eschericia coli ( $E$. coli) (Gambar 2).E. coli merupakan bakteri gram negatif yang termasuk ke dalam famili fakultatif, berbentuk batang.E. coli hidup dalam jumlah besar di dalam usus manusia, yaitu membantu sistem pencernaan manusia dan melindunginya dari bakteri patogen, dan biasanya ditemukan dalam jumlah kecil sebagai flora normal dalam saluran pernafasan dan sistem alat kelamin (Jawetz et al., 2008).

\section{Uji Resistensi Antibiotik}

Uji resistensi terhadap bakteri yang diisolasi dari Poli Gigi RSUD dr. Doris Sylvanus Palangka Raya dilakukan dengan menggunakan 3 (tiga) jenis antibiotik yang umum digunakan di poli gigi tersebut. Antibiotik yang digunakan antara lain amoxicilin, cefadroxil, dan clindamycin dengan beberapa variasi konsentrasi. 
Jumlah isolat E.coli untuk dilanjutkan dengan uji resistensi yaitu sebanyak 1 isolat dan 1 isolat untuk Staphylococcus sp., sedangkan sebanyak 2 isolat Staphylococcus sp.(kode U1 dan U2) tidak disertakan dalam pengujian resistensi terhadap antibiotika karena jumlah isolat yang sedikit, sehinggadikhawatirkan akan terjadi bias dalam pengambilan kesimpulan.

Tabel 2. Uji Resistensi Bakteri Staphylococcus sp.dan E. coli Terhadap Antibiotik

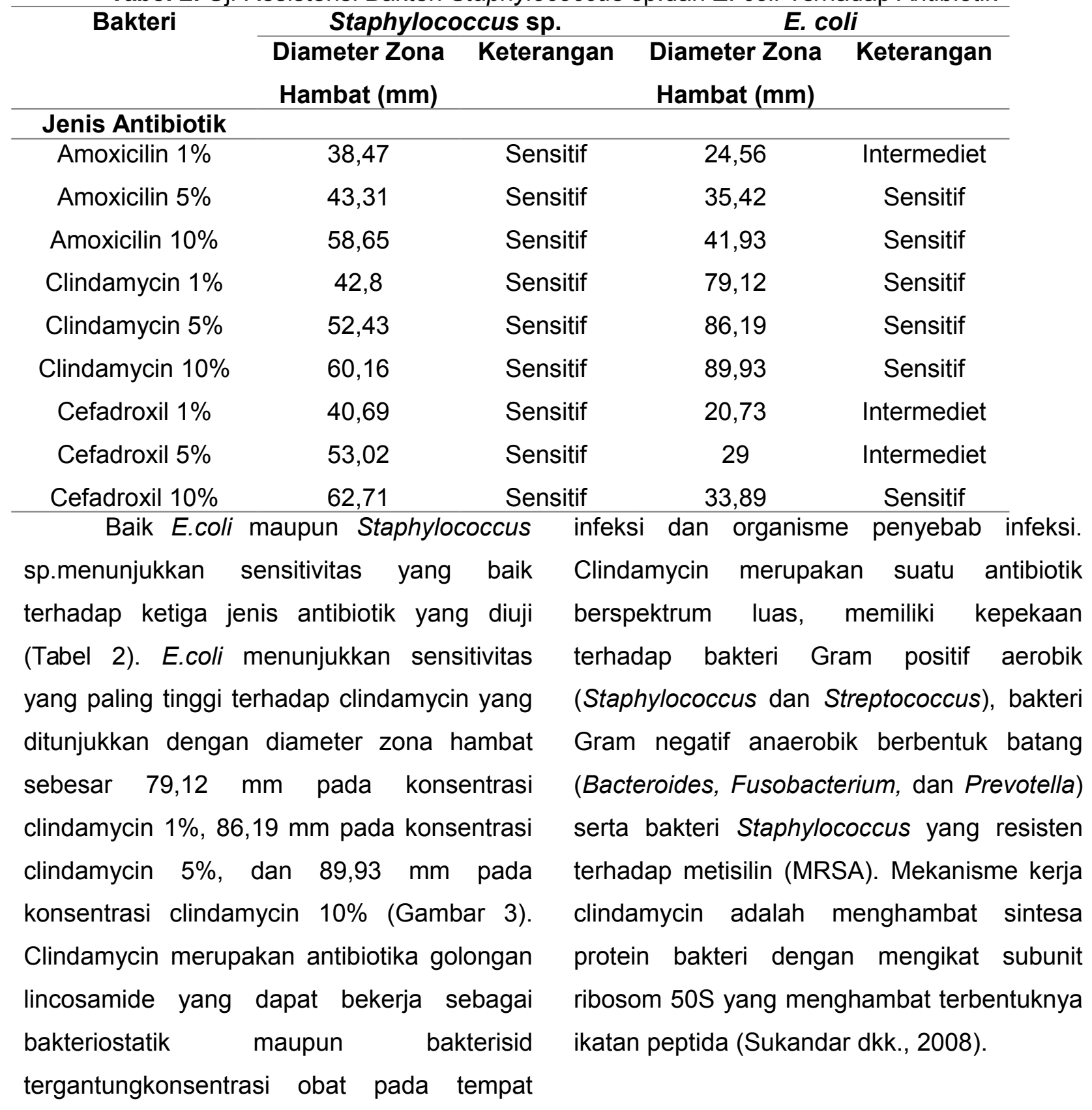




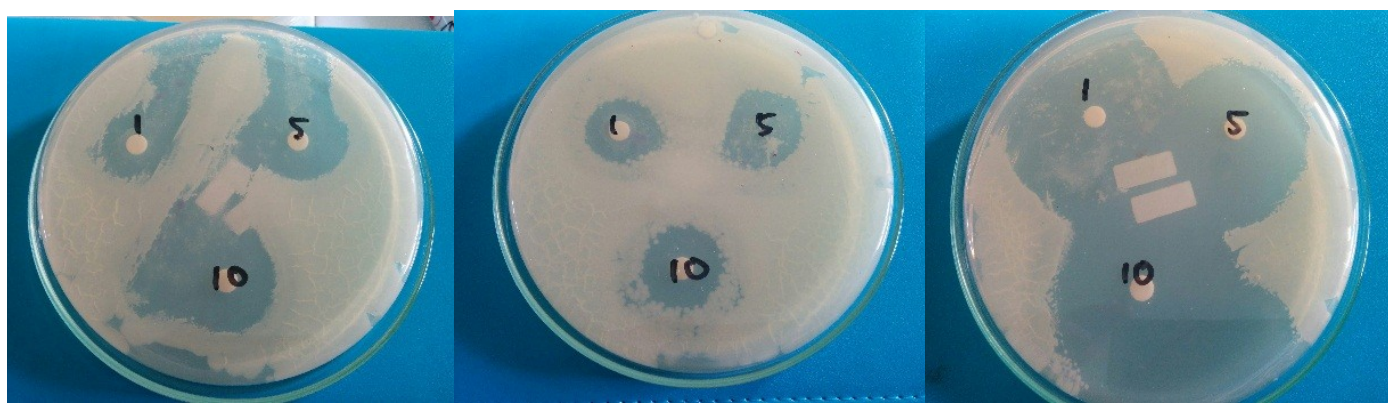

Gambar 3. Uji resistensi bakteri E. coli terhadap antibiotik amoxicilin (kiri), cefadroxil (tengah), dan clindamycin (kanan) dengan beberapa konsentrasi yaitu 1\%, 5\%, dan $10 \%$.

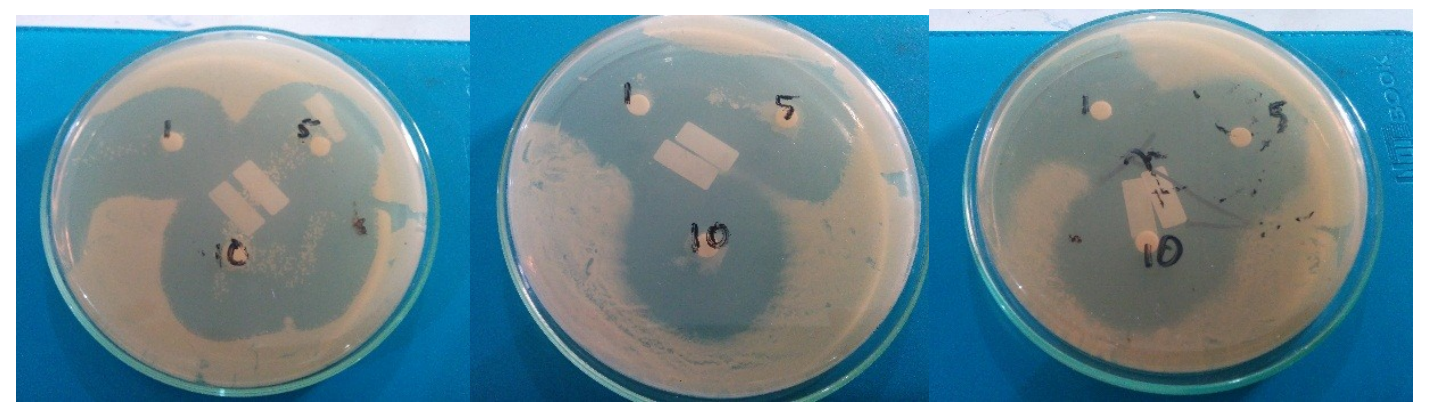

Gambar 4. Uji resistensi bakteri Staphylococcus sp.terhadap antibiotik amoxicilin (kiri), cefadroxil (tengah), dan clindamycin (kanan) dengan beberapa konsentrasi yaitu 1\%, 5\%, dan $10 \%$.

Staphylococcus sp. menunjukkan sensitivitas yang sama baiknya terhadap clindamycin dan cefadroxil (Gambar 4). Hal ini ditunjukkan dengan diameter zona hambat yang terbentuk pada uji resistensi dengan menggunakan clindamycin konsentrasi $1 \%$, $5 \%$, dan $10 \%$ yaitu masing-masing sebesar 42,8 mm; 52,43 mm; dan 60,16 mm. Pada uji resistensi dengan menggunakan cefadroxil konsentrasi $1 \%, 5 \%$, dan $10 \%$, diameter zona hambat yang terbentuk yaitu masing-masing sebesar 40,69 mm; 53,02 mm; dan 62,71mm. Sensitivitas yang ditunjukkan $E$. coli terhadap cefadroxil lebih rendah dibandingkan dengan sensitivitas yang ditunjukkan terhadap dua antibiotik lainnya. Diameter zona hambat yang terbentuk yaitu sebesar $20,73 \mathrm{~mm}$ pada konsentrasi cefadroxil 1\%, $29 \mathrm{~mm}$ pada konsentrasi cefadroxil $5 \%$, dan $33,89 \mathrm{~mm}$ pada konsentrasi cefadroxil 10\%. Berdasarkan diameter zona hambat yang terbentuk tersebut menunjukkan bahwa konsentrasi cefadroxil $1 \%$ dan $5 \%$ bersifat intermediet dalam menghambat aktivitas $E$. coli, namun sensitif pada konsentrasi $10 \%$.

Cefadroxil merupakan antibiotika semisintetik golongan sefalosforin generasi pertama. Cefadroxil bersifat bakterisid dengan jalan menghambat sintesa dinding sel bakteri. Yang dihambat ialah reaksi transpeptidase tahap ketiga dalam rangkaian reaksi pembentukan dinding sel. Cefadroxil aktif 
terhadap Streptococcus beta-hemolytic, Staphylococcus aureus (termasuk penghasil enzim penisilinase), Streptococcus pneumoniae, E. coli, Proteus mirabilis, Klebsiella sp., Moraxella catarrhalis (Sukandar dkk., 2008). Hasil uji resistensi menunjukkan bahwa jika dibandingkan dengan E. coli, Staphylococcus sp.lebih sensitif terhadap cefadroxil. Hal ini sesuai dengan pustaka bahwa senyawa-senyawa generasi pertama memiliki aktivitas yang lebih baik terhadap organisme-organisme Gram positif dibandingkan organisme-organisme Gram negatif (Katzung, 2004).

Sensitivitas yang ditunjukkan E. coli terhadap amoxicillin jauh lebih baik jika dibandingkan dengan cefadroxil. Pada konsentrasi amoxicilin 1\% terbentuk diameter zona hambat sebesar $24,56 \mathrm{~mm}$, hal ini menunjukkan bahwa pada konsentrasi tersebut amoxicilin bersifat intermediet dalam menghambat aktivitas E. coli. Sedangkan pada konsentrasi amoxicilin 5\% dan 10\% terbentuk diameter zona hambat masingmasing sebesar $35,42 \mathrm{~mm}$ dan $41,93 \mathrm{~mm}$. Staphylococcus sp.menunjukkan sensitivitas yang cukup baik terhadap amoxicilin, namun sensitivitas tersebut lebih rendah jika dibandingkan dengan sensitivitas yang ditunjukkan terhadap dua antibiotik lainnya. Pada konsentrasi amoxicilin 1\%, 5\%, dan $10 \%$ terbentuk zona hambat dengan diameter masing-masing sebesar $38,47 \mathrm{~mm} ; 43,31$ $\mathrm{mm}$; dan 58,65 mm.

Amoxicilin merupakan antibiotik yang banyak tersedia pada unit-unit pelayanan kesehatan masyarakat terutama puskesmas dan rumah sakit untuk pasien menengah ke bawah sehingga paling banyak dipakai (Refdanita et al., 2004). Amoxicilin merupakan antibiotik spektrum luas yang bersifat bakterisid. Bakteri pathogen yang sensitif terhadap amoxicilin adalah Staphylococci, Streptococci, Enterococci, dan E. coli (Sukandar dkk., 2008), sehingga dapat dilihat dari hasil bahwa amoxicilin dapat membunuh bakteri E.coli dan Staphylococcus sp. Amoxicilin merupakan salah satu turunan penisilin yang bekerja menghambat pembentukan dinding sel bakteri dengan cara mencegah penggabungan asam $\mathrm{N}$ asetimuramat yang dibentuk di dalam sel ke struktur mukopeptide yang biasanya memberikan bentuk kaku pada dinding sel bakteri (Pelczar dan Chan, 2007). Mekanisme kerja amoxicilin terhadap Staphylococcus aureus adalah dengan menghambat biosintesis dinding sel, khususnya peptidoglikan (Lim, 1998) sedangkan pada $E$. coli apabila diberikan amoxicilin akan membentuk tonjolan-tonjolan pada dinding selnya sehingga sitoplasma mengalir di dalamnya. Sel akan kehilangan sitoplasmanya karena lisis (Pelczar dan Chan, 2007). 


\section{KESIMPULAN}

Kesimpulan yang didapat dari penelitian ini adalah:

1. Telah berhasil diisolasi dan diidentifikasi bakteri Staphylococcus sp. dan E. coli dari Poli Gigi RSUD dr. Doris Sylvanus Palangka Raya.

2. Baik Staphylococcus sp. maupun E. coli menunjukkan sensitivitas yang baik terhadap ketiga antibiotik yang sering digunakan di Poli Gigi RSUD dr. Doris Sylvanus Palangka Raya.

3. Staphylococcus sp. menunjukkan sensitivitas yang tinggi terhadap cefadroxil, diikuti oleh clindamycin dan amoxicilin.

4. E. coli menunjukkan sensitivitas yang tinggi terhadap clindamycin, diikuti oleh amoxicilin dan cefadroxil.

\section{DAFTAR PUSTAKA}

1. Adam, S. 1992. Dasar-dasar Mikrobiologi dan Parasitologi untuk Perawat. Jakarta: Penerbit Buku Kedokteran EGC.

2. Brooks, G. F., Butel, J. S., and Morse, S. A. 2007. Mikrobiologi Kedokteran. Edisi 23. Jakarta: Penerbit Buku Kedokteran EGC.

3. Hadinegoro, S. R. 1999. Masalah Multi Drug Resisten pada Demam Tifoid Anak. Jakarta: Cermin Dunia Kedokteran. No. 124: 5-8.
4. Hadioetomo, R.S.1993. Mikrobiologi Dasardalam Praktek Teknik dan Prosedur Dasar Laboratorium. Jakarta: Penerbit Gramedia.

5. Irianto, K. 2013. Mikrobiologi Medis. Cetakan I. Bandung: Penerbit Alfabeta.

6. Jawetz, E., et al. 2008. Mikrobiologi Kedokteran. Edisi 20. San Fransisco: University Of California.

7. Katzung, B. G. 2004. Farmakologi Dasar dan Klinik. Edisi 4. Jakarta: Penerbit Buku Kedokteran EGC.

8. Koneman, E.W., Allen, S.D., Dowell, V.R., Janda, W.M., Sommers, H.M., Winn, W.C. 1988.Diagnostic Microbiology. Third Edition.Pennsylvania: Lippincott Company.

9. Kusmawan, A. 2008. Infeksi Nosokomial di Klinik Gigi. Skripsi. Fakultas Kedokteran Gigi. Universitas Sumatera Utara. Medan.

10. Lim, D. 1998. Microbiology. Edisi 2. New York: Mc Grow Hill Book Company.

11. Noer, S.F. 2012. Pola Bakteri dan Resistensinya Terhadap Antibiotik yang Ditemukan pada Air dan Udara Ruang Instalasi Rawat Khusus RSUP Dr. Wahidin Sudirohusodo Makassar. Majalah Farmasi dan Farmakologi, Vol. 16, No.2 Juli 2012, hlm. 73-78.

12. Pelczar, M. J., Chan, E. C. S. 2007. Elements Of Microbiology. New York: Mc Grow Hill Book Company.

13. Refdanita, Maksum R, Nurgani, Endang. 2004. Pola Kepekaan Kuman Terhadap Antibiotika di Ruang Rawat Intensif Rumah Sakit Fatmawati Jakarta Tahun 2001 - 2002. Jakarta: Makara Kesehatan, Vol. 8, No. 2,Desember : 41-48.

14. Sukandar, E. Y., dkk. 2008. ISO Farmakoterapi. Jakarta: Penerbit PT. ISFI.

15. Waluyo, L. 2008. Mikrobiologi Umum. UPT. Malang: Penerbit Universitas Muhammadiyah Malang. 